\title{
The effects of decomposing mangrove leaf litter and its tannins on water quality and the growth and survival of tiger prawn (Penaeus monodon) post-larvae
}

\author{
SRI REJEKI ${ }^{1, \bullet}$, MARCEL MIDDELJANS ${ }^{2}$, LESTARI L. WIDOWATI ${ }^{1}$, RESTIANA W. ARIYATI ${ }^{1}$, \\ TITA ELFITASARI ${ }^{1}$, ROEL H. BOSMA ${ }^{2}$ \\ ${ }^{1}$ Department of Aquaculture, Faculty Fisheries and Marine Sciences, Universitas Diponegoro. Jl. Prof. H. Soedarto, S.H., Tembalang, Semarang 50275, \\ Central Java, Indonesia. Tel.: +62-24-7474698, Fax.: +62-24-7474698, `email: sri_rejeki7356@yahoo.co.uk \\ ${ }^{2}$ Aquaculture and Fisheries Group, Wageningen University, Netherlands
}

Manuscript received: 14 May 2019. Revision accepted: 30 August 2019.

\begin{abstract}
Rejeki S, Middeljans M, Widowati LL, Ariyati RW, Elfitasari T, Bosma RH. 2019. The effects of decomposing mangrove leaf litter and its tannins on water quality and the growth and survival of tiger prawn (Penaeus monodon) post-larvae. Biodiversitas 20: 2750-2757. Shrimp farming in Demak, Indonesia is often practiced in silvo-aquaculture systems in which mangrove trees are planted on pond bunds. As such, mangrove leaves and its substrates may have impact on penaeid shrimp production. In this area, mangrove regrowth proceeded with Avicennia marina while planting is mostly done with Rhizophora apiculata. We compared the effects of decomposing fresh leaves of A. marina and R. apiculata on water quality and on the performance of Penaeus monodon postlarvae (PL). A hundred of PL21 (postlarvae aged 21 days with weight of $0.28 \mathrm{~g}$ ) were stocked in each of 30 aerated tanks containing 800 liters of brackish water (salinity of $21 \mathrm{ppt}$ ) for 37 days. Five treatments with three replicates for each mangrove species were assigned by adding into the tanks of $0.125,0.25$, and $0.5 \mathrm{~g} \mathrm{~L}^{-1}$ of air-dried leave, $0.125 \mathrm{of} \mathrm{g} \mathrm{L}^{-1}$ minced leave and $0.125 \mathrm{~g} \mathrm{~L}^{-1}$ of leachate of minced leaves. The PLs were fed 3 times daily with pellets at $10 \%$ of initial total body weight. Water quality parameters were recorded daily. Tannin, $\mathrm{H}_{2} \mathrm{~S}$ and $\mathrm{NH}_{3}-\mathrm{N}$ concentrations were measured every ten days. Prawn's body weight (BW) was measured and specific growth rate (SGR, $\%$ day $^{-1}$ ) and survival rate (SR, \%) were calculated after the end of experiment. Results were analyzed with ANOVA and Pearson's correlation. The results showed that tannin in decomposing mangrove leaf litter up to a concentration of $0.5 \mathrm{mg} \mathrm{g}^{-1}$ did not have a significant effect on water quality and on the growth and survival of $P$. monodon PL. However, increasing leaf litter concentrations showed an increase in $\mathrm{NH}_{3}-\mathrm{N}$ concentration due to organic matter degradation. The accumulation of $\mathrm{NH}_{3}-\mathrm{N}$ may have caused the slow growth of shrimp PL in A. marina treatment. Shrimp PL in leaf litter leachates treatment has a higher growth rate than those PL in regular leaf litter in relation to nutritional value. Survival and growth varied from $62 \pm 14$ to $70 \pm 8 \%$ and $3.1 \pm 2.1$ to $5.5 \pm 1.2 \%$ day $^{-1}$, respectively. Although decomposing mangrove leaves of $A$. marina and $R$. apiculata had no toxic effects on $P$. monodon PL up to a concentration of $1.25 \mathrm{~g} \mathrm{~L}^{-1}$, but causing severe mortality for shrimp in tanks without water exchange. As a conclusion, the present of mangrove leaves in brackish water ponds with insufficient water exchange can be harmful to shrimps. However, if the water exchange is good, decomposed mangrove leaves can become organic fertilizer that beneficial for the growth of natural food for the shrimps
\end{abstract}

Keywords: Ammonia-N, tannin, Avicennia marina, Penaeus monodon, Rhizophora apiculata

\section{INTRODUCTION}

In 1980s the international demand for prawn increased, and as a result, both extensive and intensive prawn cultureexpanded dramatically (Primavera et al. 1993; Rönnbäck 2002). In Indonesia, the decreasing world market price for rice caused by green revolution pushed the conversion of both paddy fields and mangrove forests into shrimp ponds. While extensive prawn culture caused mainly coastal landuse change (i.e. mangrove loss), several problems occurred due to the intensification: intrusion of saline water upland, increase of nutrients in water bodies due to feed waste and prawn excretions, and loss of capital due to disease outbreaks (Primavera 1997; Rivera-Ferre 2009). In response to unsustainable systems, integrated mangroveshrimp aquaculture systems (i.e. silvo-aquaculture) have been developed as environmentally and socioeconomically sustainable strategies for poor small-scale farmers (Primavera 2000; Fitzgerald 2002; Rönnbäck 2002). In
Indonesia, this technology was started in 1976 by the State Forestry Corporation, with the aim of rehabilitating and conserving mangrove forest, and resolving forestryfisheries conflicts (Primavera 2000).

Although silvo-aquaculture systems are more ecologically friendly with mangrove ecosystems than other types of aquaculture (Primavera 2000), they also have problems of sustainability. Decaying mangrove leaves are known to accumulate at pond ground, causing an increase in tannin levels, which together with the shade of the mangrove trees creates an acidic and anoxic environment, which ultimately results in lower shrimp production (Johnston et al. 2000; Clough et al. 2002; Nga et al. 2006). As an example, the prawn production from a silvoaquaculture pond with Avicennia marina and Rhizophora apiculata mangroves in Purworejo village, Demak district, Central Java, was at the low end with yield of 75-105 kg $\mathrm{ha}^{-1}$ per year (Tonneijck et al. 2015). 
Fitzgerald (2000) stated that high tannin concentrations may be potentially toxic to penaeid shrimp in mangroveshrimp aquaculture systems. Mangroves contain high levels of tannins (Robertson 1988), which can rise as much as $20 \%$ of the dry weight of plant material (Hernes et al. 2001). Tannins, generally divided into hydrolyzed and condensed tannins, are anti-nutritional elements with zero nutritional value, affecting protein utilization and nutritional digestibility of various herbivorous and detritivorous crustaceans and fish species (Neilson et al. 1986; Becker and Makkar 1999; Maitra and Ray 2003; Hammann and Zimmer 2015). The negative impact of $R$. apiculata mangrove on shrimp performance (Primavera 2000) was confirmed in an experiment that showed that leaf concentrations higher than $0.5 \mathrm{~g} \mathrm{~L}^{-1}$ were very lethal where leaf effects differed between mangrove species (Hai and Yakupitaga 2005). Using $R$. apiculata as a reference species, this study aimed to assess whether tannin was released by the decomposing leaves of A. marina and $R$. apiculata and which form of their leaves litter that contribute more on water quality degradation, whether this affected the growth and survival rate of $P$. monodon.

\section{MATERIALS AND METHODS}

\section{Study period and location}

The study was conducted for 40 days in Demak District, Central Java, Indonesia. The coastal areas of Demak once had extensive mangrove forests (about 6000 ha), but these areas had been converted into aquaculture where some area are applied silvo-aquaculture. The mangrove species $A$. marina and $R$. apiculata co-dominate the dikes of the pond and were therefore selected as the species used in this study. The experimental station is located in Tambakbulusan village in the Sub-district of Karang Tengah, about six kilometers from the capital of Demak.

\section{Experimental procedure}

Thirty-three tanks of $1 \mathrm{~m}^{3}(1 \times 1 \times 1 \mathrm{~m})$ were used to test the effects of decomposing mangrove leaves on water quality and on the growth and survival of $P$. monodon PL. The experimental plastic tanks of $1 \mathrm{~m}^{3}$ were filled with \pm 5 $\mathrm{cm}$ pond bottom substrate, clay-loam soil ( $\mathrm{pH}$ 6.5) and 800 liters of brackish water (salinity $21 \mathrm{ppt}$ ). The prawn PL were stocked 4 days later to let the suspended particles sediment. The water in the tanks was not exchanged but the volume was maintained by adding water from the same source regularly. Each tank was continuously aerated using Resun ${ }^{\circledR}$ LP-60 low noise air pump to maintain dissolved oxygen level above $5 \mathrm{mg} \mathrm{L}^{-1}$, thus largely above the recommended level and the $3 \mathrm{mg} \mathrm{L}^{-1}$ generally found in silvo-aquaculture (Boyd 1989; Binh et al. 1997; Johnston et al. 2002). The experimental tanks were covered with dark netting to reduce water temperature fluctuation and light intensity.
Tiger prawn (P. monodon) larvae of 21 days old, known as PL-21, at average initial body weight of $0.28 \mathrm{~g}$ were bought from the Centre of Brackish Water Research Institution (Balai Besar Penelitian Budidaya Air Payau = BBPBAP) in Jepara. PL-21 were randomly stocked in each tank at a density of 100 PLs $\mathrm{m}^{-2}$ that was acclimatized previously. During the acclimatization, dead PL were replaced by new identical individuals.

Commercial shrimp pellet produced by Central Proteinaprima Tbk. was added three times a day at 07:00, 12:00 and 18:00 to the tanks with PL at the total rate of $10 \%$ of the total stocked and adjusted after the weekly weighing. The feed was put at a $40 \times 40 \mathrm{~cm}$ feeding tray submerged at the bottom of each tank. The pellet contained $41 \%$ protein, $5 \%$ fat, $2 \%$ fiber, $13 \%$ ash and $11 \%$ moisture.

Mature green leaves of $A$. marina and $R$. apiculata were collected from mangrove pond and transported to the experimental station. The leaves were air-dried in the shade to a constant weight and separated species-wise in litter bags made of nylon nets of $3 \mathrm{~mm}$ mesh size (Figure 1.AB), and then added to the tanks nine days after collection. Stones were tied to the litter bags to make them sink.

The minced leaves were obtained by cutting the dried leaves into small pieces and mincing the cust in an electrical blender (Figure 1.C). The leave leachate was obtained by soaking $100 \mathrm{~g}$ of blended leaf litter in $2 \mathrm{~L}$ filtered brackish water for 30 minutes, then sieving through a woven wire sieve (100 $\mu \mathrm{m}$ mesh size). Only the solution was added to the tanks (Figure 1.D).

Experiment conducted by Hai and Yakupitaga (2005) found that the concentration of leaves higher than $0.5 \mathrm{~g} \mathrm{~L}^{-1}$ was very lethal. As such, three concentrations of mangrove leaves were applied in our study: $0.125,0.25$ and $0.5 \mathrm{~g} \mathrm{~L}^{-1}$. Two additional leaves treatments were applied to analyze the effects of presumed faster release of tannins to allow faster decomposition and tannin dilution: (i) $0.125 \mathrm{~g} \mathrm{~L}^{-1}$ minced $100 \mathrm{~g}$ leaf litter was cut into small pieces and minced using a blender after which added species-wise in the litter bags made from pantyhose stockings (Figure 1.C); (ii) $0.125 \mathrm{~g} \mathrm{~L}-1$ leachate $100 \mathrm{~g}$ of blended leaf litter was soaked in $2 \mathrm{~L}$ filtered brackish water for 30 minutes, after which sieved through a woven wire sieve $(100 \mu \mathrm{m}$ mesh size), and only the solution was added species-wise (Figure 1.D). All 5 treatments were done in three replications.

\section{Data collection \\ Water quality parameters}

Seven water quality parameters were measured including temperature $(\mathrm{T}), \mathrm{pH}$, salinity, dissolved oxygen (DO), tannin, hydrogen sulfide $\left(\mathrm{H}_{2} \mathrm{~S}\right)$, and unionized ammonia as nitrogen $\left(\mathrm{NH}_{3}-\mathrm{N}\right)$. Water temperature was observed daily using an electronic thermometer with precision of $0.1^{\circ} \mathrm{C}, \mathrm{pH}$ using HANNA ® HI98129 pH meter with precision of 0.01 , and salinity using ATAGO®PAL-06s refractometer 06S refractometer with precision of 1 ppt. The DO was recorded on day 6, 12, 22, 23, 30 and 33 of the study using a YSI@Pro DO meter (read-out in $0.1 \mathrm{mg} \mathrm{L}^{-1}$ ). 


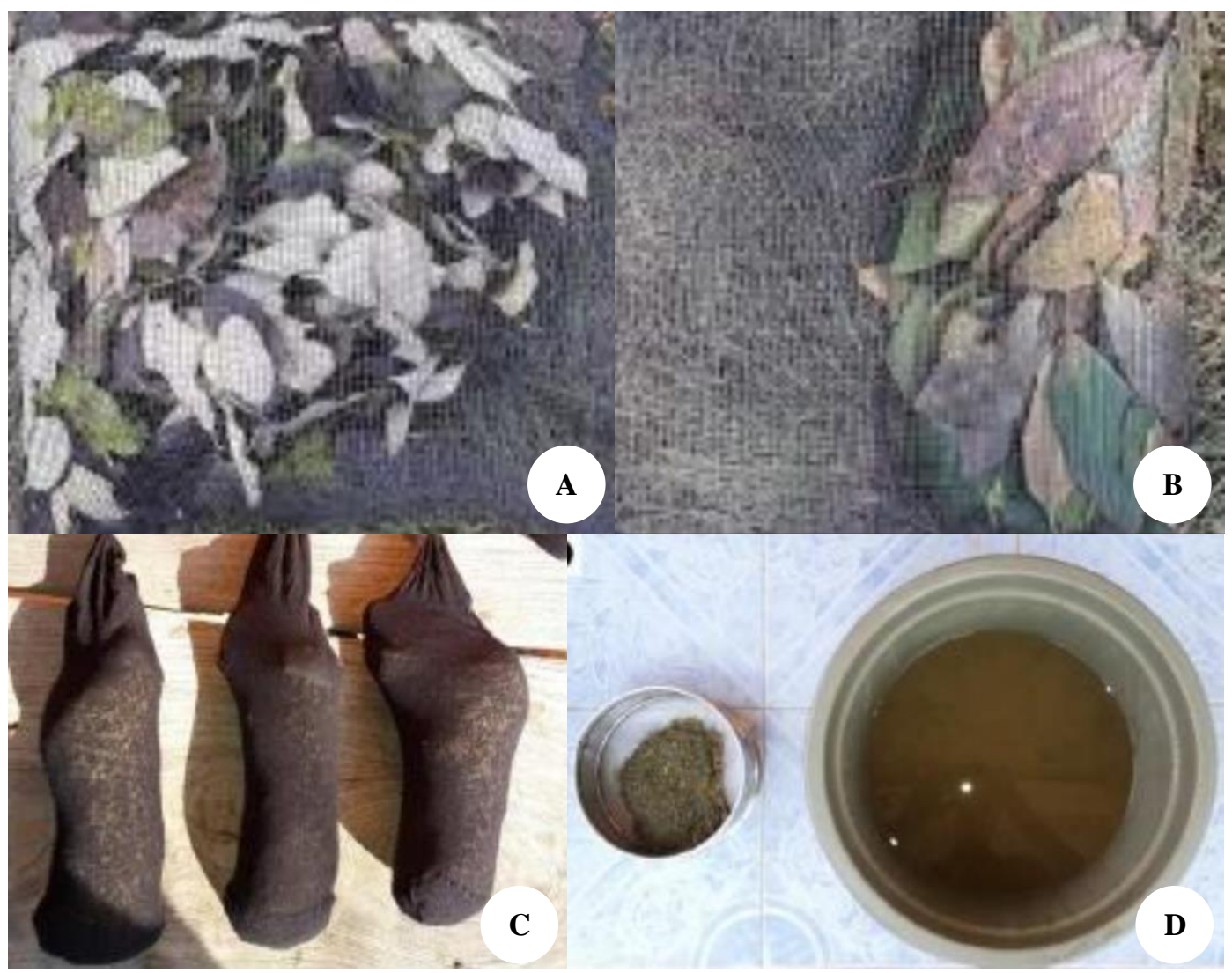

Figure 1. The decomposing mangrove leaves were separated according to different treatment (A) Litterbag with A. marina leaves; (B) litterbag with $R$. apiculata leaves; (C) minced A.marina leaves; (D) $R$. apiculata leaf litter leachate

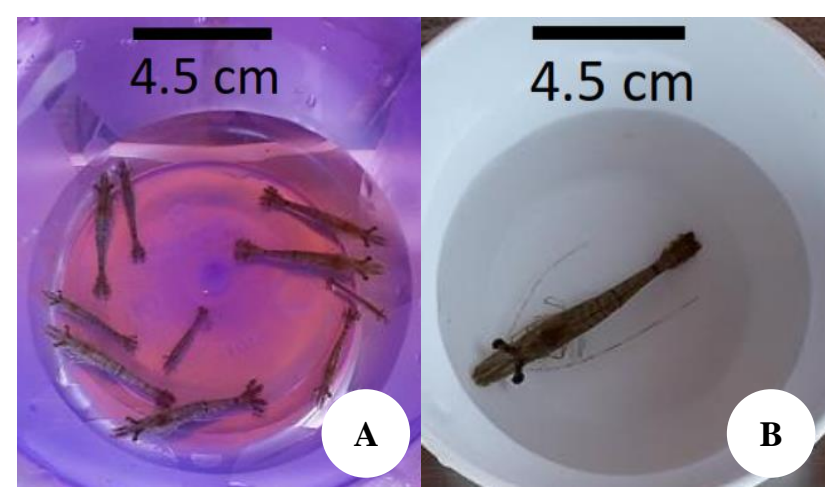

Figure 2. A. Initial body weight was measured in group of ten individuals; B. Final body weight was measured per individual

Tannin, hydrogen sulfide $\left(\mathrm{H}_{2} \mathrm{~S}\right)$ and unionized ammonia as nitrogen $\left(\mathrm{NH}_{3}-\mathrm{N}\right)$ were measured according to standard methods as described in Rice et al. (2012). Therefore, every ten days three water samples were taken from each replicate treatment: $500 \mathrm{ml}$ for tannin analysis and $200 \mathrm{ml}$ for $\mathrm{H}_{2} \mathrm{~S}$ and $\mathrm{NH}_{3}-\mathrm{N}$ analysis. For the control, only the two/three samples were aggregated before analysis. Samples for $\mathrm{H}_{2} \mathrm{~S}$ analysis were preserved by adding 8 drops of $2 \mathrm{~N}$ zinc acetate and 10 drops of sodium hydroxide $(\mathrm{NaOH})$ solution to $\mathrm{pH}>9$, while $\mathrm{NH}_{3}-\mathrm{N}$ samples were preserved by adding sulfuric acid $\left(\mathrm{H}_{2} \mathrm{SO}_{4}\right)$ to $\mathrm{pH}<2$. The
93 samples were kept in styrofoam cool boxes and being transported to Balai Besar Teknologi Pencegahan Pencemaran Industri, Semarang, for analyses. The tannin content was analyzed colorimetrically by the Folin phenol method, while $\mathrm{H}_{2} \mathrm{~S}$ and $\mathrm{NH}_{3}-\mathrm{N}$ were analyzed by the Iodometric and Phenate method, respectively.

\section{Growth performance and survival rate}

The initial body weight was determined for the whole population (i.e. 3300 prawn) by randomly sampling and weighing 35 groups of ten individuals in order to minimize fluctuations due to wind (Figure 2A). The final body weight was determined per tank by collecting and weighing all shrimp individually (Figure 2B). Weighing was done with an A\&D® HL-100 electronic weighing scale with a precision of $0.01 \mathrm{~g}$.

The specific growth rate (SGR) and survival rate (SR) were calculated with the formula of Busacker et al. (1990)

$$
\mathrm{SGR}=\frac{\ln \mathrm{BW}_{\mathrm{t}}-\ln \mathrm{BW}_{\mathrm{o}}}{\mathrm{t}} \times 100 \%
$$

Where :

$S G R$ : specific growth rate (\% day-1);

$B W \mathrm{t}$ : the final body weight $(\mathrm{g})$;

$B W \mathrm{o}$ : the itial body weight $(\mathrm{g})$; and $t$ is duration of experiment (days). 
$\mathrm{SR}=\frac{\mathrm{N}_{\mathrm{t}}}{\mathrm{N}_{\mathrm{o}}} \times 100 \%$

Where

SR: the survival rate $(\%)$;

$\mathrm{Nt}$ : the number of prawns collected at sampling time $\mathrm{t}$

No: the number of prawns initially stocked

\section{Data analyses}

Statistical analyses were done using SigmaPlot ${ }^{\circledR} 12$. Differences were considered significant at $P<0.05$. The water quality parameters and prawn performance were compared by one-way analyses of variance (ANOVA). Prior to the ANOVA, all data were checked for their normality using the Shapiro-Wil test. When data were not normally distributed, a non-parametric Kruskal-Wallis test by ranks was used. If the ANOVA showed the treatment significantly affected the variables, a multiple comparison Duncan and Tukey posthoc test was done. Correlations among the water quality parameters, between the water quality parameters and growth, and between the water quality parameters and survival rate, were analyzed using Pearson's correlation coefficient.

\section{RESULTS AND DISCUSSION}

\section{Water quality parameters}

The levels of salinity, temperature, and DO did not differ significantly between the treatments throughout the experiment (Table 1). Since the experimental tanks are closed system, the salinity levels fluctuated between 19 and $25 \mathrm{ppt}$ (mean $22 \pm 1 \mathrm{ppt}$ ) and the water temperature between 27.2 and $33.3^{\circ} \mathrm{C}$ (mean $30.6 \pm 1.4{ }^{\circ} \mathrm{C}$ ) but the DO slightly varied from 6.3 to $6.9 \mathrm{mg} \mathrm{L}^{-1}$ (mean $6.7 \pm 0.5 \mathrm{mg} \mathrm{L}^{-1}$ ). Although the DO concentration of the culture media was high and in the upper side of the recommended range $( \pm 4$ $\mathrm{mg} \mathrm{\textrm {L } ^ { - 1 } )}$ all recorded salinity, temperature, and DO concentrations were considered as optimal for P. monodon PL.

The majority of the treatments had undetectable $\mathrm{H}_{2} \mathrm{~S}$ concentrations $\left(<0.002 \mathrm{mg} \mathrm{L}^{-1}\right) . \mathrm{H}_{2} \mathrm{~S}$ was only detected in 11 of the 30 tanks during the research period; most measured concentrations were 0.002 and $0.003 \mathrm{mg} \mathrm{L}^{-1}$. For both A. marina and $R$. apiculata the highest levels were found for the treatment with 0.125 leachate: 0.005 and $0.004 \mathrm{mg} \mathrm{L}^{-1}$, respectively. Therefore no reliable conclusion can be made about the influence of mangrove leaf litter concentrations on $\mathrm{H}_{2} \mathrm{~S}$ production.

The $\mathrm{NH}_{3}-\mathrm{N}$ concentration found in all treatments exceeded the optimal level for penaeid PL and were considered critical and lethal. Leaf litter concentrations increased the NH3-N concentration in both A. marina and $R$. apiculata treatments, but this did not differ significantly $(\mathrm{H}=6.124, \mathrm{df}=3, \mathrm{P}=0.106)$ (Table 2.A).

The average $\mathrm{NH}_{3}-\mathrm{N}$ concentrations in the leaf treatments for A. marina compared to $R$. apiculata, $0.83 \pm$ 0.2 and $0.79 \pm 0.2 \mathrm{mgL}^{-1}$, respectively, were not significantly different (Table 2.B). However, species-wise, $\mathrm{NH}_{3}-\mathrm{N}$ concentration was not also significantly affected by the leaf treatments $(\mathrm{H}=0.230, \mathrm{df}=1, \mathrm{P}=0.631)$.

The concentration of mangrove leaf litter did not significantly affect tannins in water $(P=0.967)$ (Table 2A). However, the average tannin concentration in the tanks increased during leaf decomposition, from $0.68 \pm 0.40 \mathrm{mg}$ $\mathrm{L}^{-1}$ on day 12 to $3.72 \pm 0.23 \mathrm{mg} \mathrm{L}^{-1}$ on day 33 of decomposition for the treatments of A. marina and similarly from $0.49 \pm 0.15 \mathrm{mg} \mathrm{L}^{-1}$ on day 12 to $3.91 \pm 0.19$ $\mathrm{mg} \mathrm{L}^{-1}$ on day 33 of decomposition for the treatments of $R$. apiculata (Figure 3).

Although overall mean tannin concentration was recorded higher in the treatments with leaves of $R$. apiculata $\left(2.07 \pm 1.45 \mathrm{mg} \mathrm{L}^{-1}\right)$ compared to the treatments with $A$. marina leaves $\left(1.92 \pm 1.37 \mathrm{mg} \mathrm{L}^{-1}\right)$ (Table $2 \mathrm{~B}$ ), no clear trend can be detected from the treatments between the species $(\mathrm{H}=0.257$, df $=1, \mathrm{P}=0.612)$.

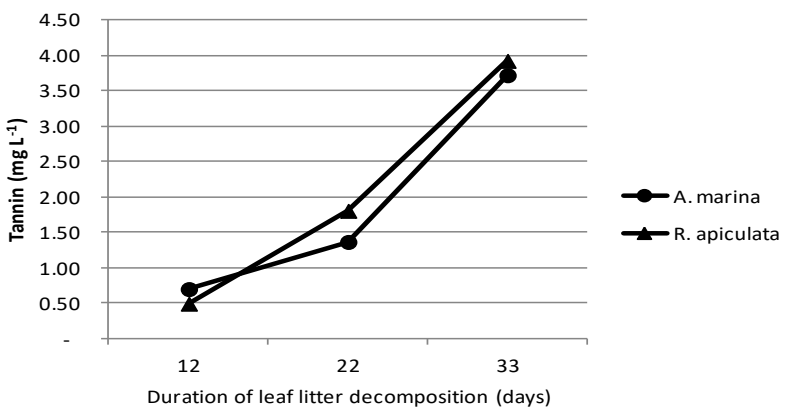

Figure 3. The mean tannin concentrations of A. marina and $R$. apiculata treatments increased gradually during the study period

Table 1. The mean \pm standard deviation of salinity (ppt), Dissolved Oxygen (DO), temperature $(\mathrm{T})$ and $\mathrm{pH}$ for each treatment

\begin{tabular}{|c|c|c|c|c|c|c|}
\hline \multirow[b]{2}{*}{$\begin{array}{l}\text { Leaf litter }\left(\mathrm{gL}^{-1}\right) \\
\text { concentration }\end{array}$} & \multicolumn{3}{|c|}{ A. marina } & \multicolumn{3}{|c|}{ R. apiculata } \\
\hline & $\begin{array}{c}\text { Salinity } \\
\text { (ppt) }\end{array}$ & $\begin{array}{c}\text { DO } \\
\left(\mathrm{mg} \mathrm{L}^{-1}\right)\end{array}$ & $\begin{array}{c}T \\
\left({ }^{\circ} \mathrm{C}\right) \\
\end{array}$ & $\begin{array}{c}\text { Salinity } \\
\text { (ppt) }\end{array}$ & $\begin{array}{c}\text { DO } \\
\left(\mathrm{mg} \mathrm{L}^{-1}\right) \\
\end{array}$ & $\begin{array}{c}T \\
\left({ }^{\circ} \mathrm{C}\right) \\
\end{array}$ \\
\hline \multicolumn{7}{|c|}{ A (leaf concentration) } \\
\hline 0.125 & $21 \pm 1$ & $6.6 \pm 0.3$ & $30.1 \pm 1.4$ & $23 \pm 1$ & $6.9 \pm 0.5$ & $30.6 \pm 1.4$ \\
\hline 0.25 & $22 \pm 1$ & $6.7 \pm 0.6$ & $30.2 \pm 1.4$ & $22 \pm 1$ & $6.8 \pm 0.6$ & $30.6 \pm 1.3$ \\
\hline 0.5 & $23 \pm 1$ & $6.3 \pm 0.3$ & $30.4 \pm 1.4$ & $21 \pm 1$ & $6.5 \pm 0.6$ & $30.4 \pm 1.4$ \\
\hline \multicolumn{7}{|l|}{ B (leaf treatment) } \\
\hline 0.125 whole & $21 \pm 1$ & $6.6 \pm 0.3$ & $30.1 \pm 1.4$ & $23 \pm 1$ & $6.9 \pm 0.5$ & $30.6 \pm 1.4$ \\
\hline 0.125 minced & $23 \pm 1$ & $6.8 \pm 0.3$ & $30.6 \pm 1.3$ & $22 \pm 1$ & $6.8 \pm 0.5$ & $30.6 \pm 1.4$ \\
\hline 0.125 leachate & $22 \pm 1$ & $6.9 \pm 0.4$ & $30.9 \pm 1.5$ & $22 \pm 1$ & $6.6 \pm 0.4$ & $30.6 \pm 1.3$ \\
\hline
\end{tabular}


Table 2. Mean and standard deviation (SD) of the concentrations of $\mathrm{NH}_{3}-\mathrm{N}\left(\mathrm{m} \cdot \mathrm{L}^{-1}\right)$ and tannin for the treatments with $A$. marina and $R$. apiculata, the P-value of the ANOVA and results of the posthoc tests (values in the same column having a different letter are significantly different)

\begin{tabular}{|c|c|c|c|c|c|c|}
\hline \multirow{2}{*}{ Treatments } & \multicolumn{3}{|c|}{ NH3-N } & \multicolumn{3}{|c|}{ Tannin } \\
\hline & A. marina & R. apiculata & Mean & A. marina & R. apiculata & Mean \\
\hline \multicolumn{7}{|c|}{ A (leaf concentration) } \\
\hline 0.125 & $0.82 \pm 0.3^{\mathrm{a}}$ & $0.74 \pm 0.2^{\mathrm{a}}$ & $0.8 \pm 0.2^{\mathrm{A}}$ & $1.77 \pm 1.5^{\mathrm{a}}$ & $2.21 \pm 1.5^{\mathrm{a}}$ & $2.0 \pm 1.5^{\mathrm{A}}$ \\
\hline 0.25 & $0.95 \pm 0.3^{\mathrm{a}}$ & $0.82 \pm 0.2^{\mathrm{a}}$ & $0.9 \pm 0.2^{\mathrm{A}}$ & $1.86 \pm 1.5^{\mathrm{a}}$ & $1.92 \pm 1.5^{\mathrm{a}}$ & $1.9 \pm 1.4^{\mathrm{A}}$ \\
\hline 0.5 & $0.99 \pm 0.2^{\mathrm{a}}$ & $0.87 \pm 0.2^{\mathrm{a}}$ & $0.9 \pm 0.2^{\mathrm{A}}$ & $2.16 \pm 1.4^{\mathrm{a}}$ & $1.97 \pm 1.5^{\mathrm{a}}$ & $2.1 \pm 1.4^{\mathrm{A}}$ \\
\hline \multicolumn{7}{|l|}{ B (leaf treatment) } \\
\hline 0.125 Whole & $0.82 \pm 0.3^{\mathrm{a}}$ & $0.74 \pm 0.2^{\mathrm{a}}$ & $0.8 \pm 0.2^{\mathrm{A}}$ & $1.77 \pm 1.5^{\mathrm{a}}$ & $2.21 \pm 1.5^{\mathrm{a}}$ & $2.0 \pm 1.5^{\mathrm{A}}$ \\
\hline 0.125 Minced & $0.75 \pm 0.1^{\mathrm{a}}$ & $0.76 \pm 0.2^{\mathrm{a}}$ & $0.8 \pm 0.2^{\mathrm{A}}$ & $1.83 \pm 1.4^{\mathrm{a}}$ & $2.21 \pm 1.6^{\mathrm{a}}$ & $2.0 \pm 1.5^{\mathrm{A}}$ \\
\hline 0.125 Leachate & $0.69 \pm 0.1^{\mathrm{a}}$ & $0.76 \pm 0.2^{\mathrm{a}}$ & $0.7 \pm 0.2^{\mathrm{A}}$ & $2.03 \pm 1.46^{\mathrm{a}}$ & $2.02 \pm 1.6^{\mathrm{a}}$ & $2.0 \pm 1.5^{\mathrm{A}}$ \\
\hline Mean & $0.83 \pm 0.2^{\mathrm{A}}$ & $0.79 \pm 0.2^{\mathrm{A}}$ & & $1.92 \pm 1.4^{\mathrm{A}}$ & $2.07 \pm 1.5^{\mathrm{A}}$ & \\
\hline
\end{tabular}

Table 3. Mean and standard deviation of the final body weight and survival rate for the treatments with A. marina and $R$. apiculata, and the results of the posthoc tests (values in the same column having a different letter are significantly different at $\mathrm{P}<0.05$ )

\begin{tabular}{|c|c|c|c|c|c|c|}
\hline \multirow{2}{*}{ Treatments } & \multicolumn{3}{|c|}{ Shrimp growth rate $(\mathrm{SGR})\left(\%\right.$ day $\left.^{-1}\right)$} & \multicolumn{3}{|c|}{ Survival rate $(\mathrm{SR})(\%)$} \\
\hline & A. marina & R. apiculata & Mean & A. marina & R. apiculata & Mean \\
\hline \multicolumn{7}{|c|}{ A (leaf concentration) } \\
\hline 0.125 & $4.92 \pm 0.5^{\mathrm{bc}}$ & $4.78 \pm 0.2^{\mathrm{bc}}$ & $4.03 \pm 1.1^{\mathrm{B}}$ & $62 \pm 16^{a}$ & $72 \pm 15^{\mathrm{a}}$ & $68 \pm 15^{\mathrm{A}}$ \\
\hline 0.25 & $4.77 \pm 0.5^{\mathrm{bc}}$ & $5.15 \pm 0.5^{\mathrm{b}}$ & $4.96 \pm 0.3^{\mathrm{BC}}$ & $66 \pm 13^{\mathrm{a}}$ & $58 \pm 16^{\mathrm{a}}$ & $62 \pm 14^{\mathrm{A}}$ \\
\hline 0.5 & $4.58 \pm 0.1^{\mathrm{c}}$ & $5.51 \pm 0.1^{\mathrm{a}}$ & $4.28 \pm 1.7^{\mathrm{AC}}$ & $86 \pm 13^{\mathrm{a}}$ & $52 \pm 2^{\mathrm{a}}$ & $66 \pm 20^{\mathrm{A}}$ \\
\hline \multicolumn{7}{|l|}{ B (leaf treatment) } \\
\hline 0.125 Whole & $4.92 \pm 0.5^{\mathrm{b}}$ & $4.78 \pm 0.2^{b}$ & $4.03 \pm 1.1^{\mathrm{B}}$ & $62 \pm 16^{\mathrm{a}}$ & $72 \pm 15^{\mathrm{a}}$ & $68 \pm 15^{\mathrm{A}}$ \\
\hline 0.125 Minced & $5.02 \pm 0.1^{\mathrm{ab}}$ & $5.29 \pm 0.1^{\mathrm{a}}$ & $5.16 \pm 0.2^{\mathrm{B}}$ & $75 \pm 8^{a}$ & $65 \pm 4^{\mathrm{a}}$ & $70 \pm 8^{\mathrm{A}}$ \\
\hline 0.125 Leachate & $5.41 \pm 0.3^{\mathrm{a}}$ & $5.07 \pm 0.2^{\mathrm{ab}}$ & $5.24 \pm 0.3^{\mathrm{B}}$ & $58 \pm 6^{\mathrm{a}}$ & $67 \pm 4^{\mathrm{a}}$ & $62 \pm 7^{\mathrm{A}}$ \\
\hline Mean & $4.31 \pm 1.1^{\mathrm{A}}$ & $5.16 \pm 0.3^{\mathrm{B}}$ & & $69 \pm 13^{\mathrm{A}}$ & $63 \pm 11^{\mathrm{B}}$ & \\
\hline
\end{tabular}

Table 4. Pearson's correlation coefficients (Pcc) between the water quality parameters: DO, pH, tannin, and $\mathrm{NH}_{3}-\mathrm{N}$ on Penaeus monodon PL growth and survival for A. marina and $R$. apiculata treatments.

\begin{tabular}{|c|c|c|c|c|c|c|}
\hline & & & DO & pH & Tannin & $\mathrm{NH}_{3}-\mathrm{N}$ \\
\hline \multirow{5}{*}{ 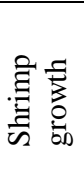 } & A. marina & Pcc & 0.48 & 0.64 & 0.25 & -0.71 \\
\hline & $(\mathrm{n}=16)$ & $\mathrm{P}$ Value & 0.06 & 0.01 & 0.35 & 0.002 \\
\hline & R. apiculata & Pcc & -0.2 & -0.52 & -0.39 & 0.05 \\
\hline & $(\mathrm{n}=18)$ & P Value & 0.43 & 0.03 & 0.11 & 0.85 \\
\hline & A. marina & Pcc & -0.53 & -0.49 & 0.07 & 0.53 \\
\hline \multirow{3}{*}{ 甾: } & $(n=16)$ & P Value & 0.04 & 0.06 & 0.79 & 0.036 \\
\hline & R. apiculata & Pcc & 0.07 & 0.36 & 0.55 & -0.16 \\
\hline & $(\mathrm{n}=18)$ & P Value & 0.79 & 0.14 & 0.02 & 0.54 \\
\hline
\end{tabular}
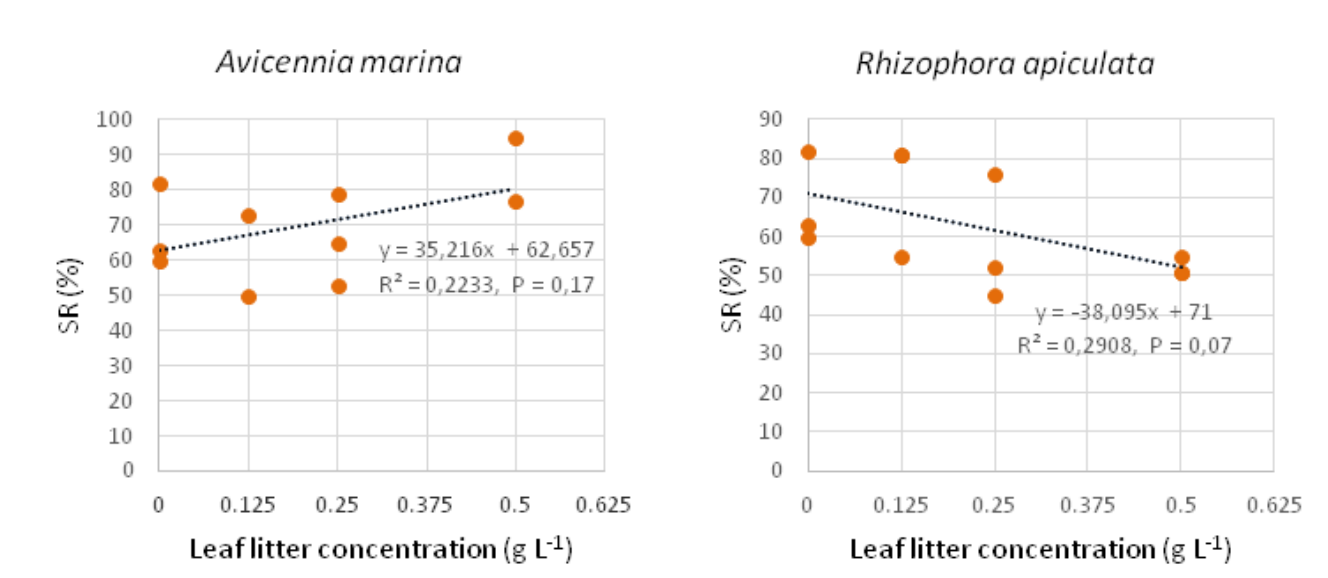

Figure 4. Multiple linear regression analysis of PL survival rate and concentrations of decomposing A. marina and R. apiculata leaf litter. The Pearson correlation coefficient between PL survival rate and A. marina leaf litter was $r=0.473, P=0.17$ and between PL survival rate and $R$. apiculata leaf litter $r=-0.539, P=0.07$. 


\section{Shrimp growth and survival rate}

Shrimp biomass relatively increased with increasing concentrations of decomposing mangrove leaves in $R$. apiculate than in A. marina (Table 3A). In A. marina tanks, the highest growth rate (SGR) was found in the $0.125 \mathrm{~g} \mathrm{~L}^{-1}$ concentration, while in $R$. apiculata tanks, the highest was in the $0.5 \mathrm{~g} \mathrm{~L}^{-1}$ concentration.

A significantly higher mean shrimp biomass was also observed in minced leaf litter $\left(5.16 \pm 0.2 \%\right.$ day $\left.^{-1}\right)$ and leaf litter leachate $\left(5.24 \pm 0.3 \%\right.$ day $\left.^{-1}\right)$ compared to leaf litter $\left(4.03 \pm 1.1 \%\right.$ day $\left.^{-1}\right)$ in the $0.125 \mathrm{~g} \mathrm{~L}^{-1}$ treatments $(\mathrm{H}=$ 34.534, $\mathrm{df}=2, \mathrm{P}<0.001$ ) (Table 3B). In A. marina tanks, shrimp body weight was significantly higher in the $0.125 \mathrm{~g}$ $\mathrm{L}^{-1}$ leachate concentration than in the $0.125 \mathrm{~g} \mathrm{~L}^{-1}$ leaf litter concentration (Dunn's post hoc, $\mathrm{Q}=4.769$ ), while in $R$. apiculata tanks, shrimp body weight in the $0.125 \mathrm{~g} \mathrm{~L}^{-1}$ minced leaf litter was significantly higher than in the 0.125 $\mathrm{g} \mathrm{L}^{-1}$ leaf litter concentration (Dunn's post hoc, $\mathrm{Q}=4.491$ ).

The highest overall survival rate was recorded at 0.125 $\mathrm{g} \mathrm{L}^{-1}$ minced leaf litter with a rate of $70.2 \pm 7.6 \%$ and the lowest overall was recorded at $0.25 \mathrm{~g} \mathrm{~L}^{-1}$ with a rate of 61.7 $\pm 13.9 \%$. However, among the concentrations, an increase in litter concentration did not lead to a significantly lower survival rate (ANOVA, $\mathrm{F}=0.198, \mathrm{df}=3, \mathrm{P}=0.896$ ) (Table 3.A). There was also no significant difference in survival rate between litter concentrations and the control $(P \geq 0.05)$. SR of shrimp in the leachate treatments was also relatively lower than those in the minced treatments, but the differences were not significant $(\mathrm{H}=2.148, \mathrm{df}=2$, $\mathrm{P}=0.342$ ) (Table 3.B)

In general, survival was significantly higher in $A$. marina treatments (mean $69 \pm 13 \%$ ) than in R. apiculata treatments (mean $63 \pm 11 \%)(\mathrm{H}=10.464, \mathrm{df}=1, \mathrm{P}=$ 0.001). An increase in decomposing leaf litter led to an increase in survival rate in the A. marina treatments $(r=$ $0.473, \mathrm{P}=0.17)$, but to a decrease in survival rate in the $R$. apiculata treatments $(r=-0.539, \mathrm{P}=0.07)$, although not significant (Figure 4).

\section{Correlations between water quality, growth, and survival}

Pearson's correlation coefficient showed various water quality parameters having negative and positive effects on shrimp growth and survival between A. marina and $R$. apiculata treatments (Table 4).

The $\mathrm{pH}$ had a positive correlation with growth of shrimp in A. marina leaf litter $(r=0.64, P=0.008)$, while this was negative in $R$. apiculata leaf litter $(r=-0.52, P=$ 0.027). The DO levels and tannin concentration in both $A$. marina and $R$. apiculata treatments were not correlated with shrimp growth $(P \geq 0.05)$. However, the higher shrimp growth was significantly correlated to a higher shrimp mortality in both A. marina $(r=-0.68, P=0.004)$ and $R$. apiculata $(r=-0.69, P=0.002)$ treatments.

Shrimp survival was positively correlated with tannin concentration in $R$. apiculata treatments $(r=0.55, P=$ 0.019). Similar results were observed for $\mathrm{NH}_{3}-\mathrm{N}$ in $A$. marina treatments $(r=0.526, \mathrm{P}=0.036)$. Shrimp survival and $\mathrm{NH}_{3}-\mathrm{N}$ in $A$. marina treatments were positively correlated $(r=0.53, P=0.036)$, while the correlation with $\mathrm{NH}_{3}-\mathrm{N}$ was strongly negative for growth $(r=-0.71, P=$ 0.002 ). However, no significant correlation was observed between shrimp growth and $\mathrm{NH}_{3}-\mathrm{N}$ in $R$. apiculata treatments. The $\mathrm{pH}$ and $\mathrm{DO}$ concentrations were not correlated with shrimp survival in both A. marina and $R$. apiculata treatments.

\section{Discussion \\ Tannin concentrations}

In this study, there was relatively higher leaching of tannins in $R$. apiculata than in A. marina treatments within 33 days (Figure 2). Previous studies showed that within 40 days there was a $50 \%$ reduction of the initial weight of $A$. marina and $R$. apiculata leaves, with the latter having slower leaching of dissolved organic matter initially (e.g. tannins) (Boonruang 1984; Robertson 1988; Rajendran and Kathiresan 2000). The loss through leaching may depend on various parameters such as species and environment, for example, leaching is higher in the wet season compared to dry season (Robertson 1988; Tam et al. 1990; Wafar et al. 1997). A. marina leaves have thinner leaf cuticle, higher initial nitrogen concentration, lower $\mathrm{C}: \mathrm{N}$ ratio and contain less tannins, thus decompose relatively faster than $R$. apiculata leaves (Robertson 1988; Camilleri 1989; Steinke et al. 1990).

During decomposition, the nitrogen concentration in both A. marina and $R$. apiculata leaves initially decreases due to leaching, after which it gradually increases due to nitrogen immobilization, leading to a decrease in C:N ratio (Robertson 1988; Benner et al. 1990; Tam et al. 1990; Dick and Osunkoya 2000; Rajendran and Kathiresan 2000, 2007). Microbial activity is primarily responsible for the immobilization of nitrogen (Tremblay and Benner 2006). This may be an important mechanism of nitrogen accumulation in leaf litter.

\section{Effect of tannin on other water quality parameters}

Increasing leaf litter concentrations did not have a significant effect on DO, tannin and $\mathrm{H}_{2} \mathrm{~S}$ concentrations and means were randomly divided over the treatments (Table 1 and 3). However, the $\mathrm{pH}$ significantly decreased with increasing leaf litter concentrations, and the $\mathrm{NH}_{3}-\mathrm{N}$ concentration increased to levels critical and lethal for the shrimp PL. The relatively higher $\mathrm{NH}_{3}-\mathrm{N}$ concentrations in the A. marina treatments may be due to its high protein content and rapid nutrient leaching rates. The decrease in $\mathrm{pH}$ with increasing leaf litter concentrations could be due to the tannin content in the leaves as was observed in previous studies (Chyau et al. 2006; Nugroho et al. 2016). In contrast, Hai and Yakupitiyage (2005) observed tannin being significantly correlated with DO $(r=-0.482), \mathrm{pH}(r=$ $0.595)$ and $\mathrm{H}_{2} \mathrm{~S}(r=0.738)$, but not with the total ammonia nitrogen (TAN). Hai and Yakupitiyage (2005) suggested that a combination of these factors could increase the toxicity of tannins to shrimp growth and survival. 


\section{Growth and survival}

In this study, the highest growth rates were found in the $0.125 \mathrm{~g} \mathrm{~L}^{-1}$ leachate concentration with presumed faster leaching of tannins, i.e. minced leaf litter and leaf litter leachate, compared to regular leaf litter. Minced leaf litter has been tested regarding mimic the phase of decomposing process in nature. This is in line with findings from the study by Nga et al. (2006), who also observed significant higher growth rates when PL was grown in water containing $R$. apiculata leaf litter leachates than when grown in water containing different concentrations of leaf litter. In addition, $P$. monodon PL in Terminalia catappa (a mangrove associated species) leaf litter leachates had a higher growth rate than those PL in controls $(\mathrm{P}<0.05)$ (Ikhwanuddin et al. 2014). The higher body weight of shrimp in leaf litter leachate than those in leaf litter is probably due to the leachates their higher nutritional value (i.e. leached proteins from dissolved organic carbon) (Davis et al. 2003).

Furthermore, increasing leaf litter concentrations showed an increase in $\mathrm{NH}_{3}-\mathrm{N}$ concentration due to organic matter degradation. The accumulation of $\mathrm{NH}_{3}-\mathrm{N}$ may have caused the slow growth in A. marina treatments as a strong negative correlation was observed $(r=-0.709, \mathrm{P}=0.002)$. This was in line with observations from Wickins (1976) and Chin and Chen (1987), who found high $\mathrm{NH}_{3}-\mathrm{N}$ concentrations reducing the growth of $P$. monodon and other penaeid shrimp PL, where the sensitive $\mathrm{NH}_{3}-\mathrm{N}$ concentration was higher than $0.1 \mathrm{mg} \mathrm{L}^{-1}$.

In the present study, the mean survival rate was significantly higher in A. marina treatments at $68.5 \pm 13.4$ $\%$ than in $R$. apiculata treatments at $62.9 \pm 11.3 \%$. The correlation between shrimp survival might be due to the tannin concentration, which increasing tannin might be related to a higher shrimp survival. Regarding the effect of A. marina in increasing the survival rate of shrimp, it is recommended that in the shrimp farm area can be covered with $A$. marina rather than $R$. apiculata. Ikhwanuddin et al. (2014) also observed a significantly higher survival rate of P. monodon PL in treatments with a concentration of $3 \mathrm{~g} \mathrm{~L}^{-}$ ${ }^{1} T$. catappa leaf litter leachate than in controls and $1 \mathrm{~g} \mathrm{~L}^{-1}$, $2 \mathrm{~g} \mathrm{~L}^{-1}$ and $4 \mathrm{~g} \mathrm{~L}^{-1}$ leaf litter leachate $(\mathrm{P}<0.05)$. Furthermore, Harlina et al. (2015) observed Chromolaena odorata (a mangrove associated species) leaf extract with its active secondary metabolites such as flavonoids, tannins and alkaloids, to have no toxic effects on P. monodon PL up to a concentration of $1.25 \mathrm{~g} \mathrm{~L}^{-1}$, but causing severe mortality above $2.5 \mathrm{~g} \mathrm{~L}^{-1}$.

Shrimp mortality in treatments with high concentrations of decomposing mangrove leaf litter is probably due to the increasing $\mathrm{NH}_{3}$ and decreasing water $\mathrm{pH}$ (toxic environment). However, low $\mathrm{pH}$ was not observed in the present study. This significant negative impact of survival rate on growth for both $A$. marina and $R$. apiculata might be due to the constant level of feeding. Feeding was not adjusted to the increased biomass. Consequently, the bigger PL might feed not only the dead PL but also the smaller PL when the latter are molting and unable to defend (Abdussamad and Thampy 1994; Ray and Chien 1992). Beside the cannibalism, the shrimp mortality is probably due to the high $\mathrm{NH}_{3}-\mathrm{N}$ concentrations (toxic environment) caused by decomposing organic matter (i.e. leaf litter and dead shrimp). The $\mathrm{NH}_{3}-\mathrm{N}$ levels in treatments with decomposing mangrove leaves of $A$. marina and $R$. apiculata were toxic for prawn in tanks without water exchange.

One of the factors that determine the success of tiger shrimp (Penaeus monodon) cultivation in the ponds is the availability of good quality seeds in sufficient quantities, because by stocking good quality seeds and supported by a good cultivation environment, the expected level of production will be obtained. One effort to get quality seeds is by rearing the post larve stage up to juvenile stage that lasts between 15-45 days, or depending on health and size of the fry (Hendrajat 2007). There are several advantages of stocking shrimp juvenile, i.e. of fry with relatively cheap prices at a certain time, can shorten the culture time in the pond, reduce the amount of feed, increase production, and survival rate in enlargement plots, and can increase harvest frequency (Mangampa et al. 2014).

In conclusion, tannin in decomposing mangrove leaf litter up to a concentration of $0.5 \mathrm{mg} \mathrm{g}^{-1}$ did not have a significant effect on water quality and on the growth and survival of $P$. monodon PL. However, increasing leaf litter concentrations showed an increase in $\mathrm{NH}_{3}-\mathrm{N}$ concentration due to organic matter degradation. The accumulation of $\mathrm{NH}_{3}-\mathrm{N}$ may have caused the slow growth of shrimp PL in A. marina treatments. Shrimp PL in leaf litter minced and leachates treatments have a higher growth rate than those $\mathrm{PL}$ in regular leaf litter. This result suggests that leaf litter leachates have a higher nutritional value as leached proteins for the shrimp.

\section{ACKNOWLEDGEMENTS}

Great appreciation is addressed to the NOW-WOTRO which provided funding for this research through PASMI Project, Faculty of Fisheries and Marine Sciences University of Diponegoro and Wageningen University and Research for in-kind facilities, all students who have assisted in the implementation of this research.

\section{REFERENCES}

Abdussamad EM, Thampy DM. 1994. Cannibalism in the tiger shrimp Penaeus monodon Fabricius in nursery rearing phase. J Aquacult Trop 9 (1): 67-75

Becker K, Makkar HPS. 1999. Effects of dietary tannic acid and quebracho tannin on growth performance and metabolic rates of common carp (Cyprinus carpio L.). Aquaculture 175 (3): 327-335.

Benner R, Hatcher PG, Hedges JI. 1990. Early diagenesis of mangrove leaves in a tropical estuary: Bulk chemical characterization using solid-state 13C NMR and elemental analyses. Geochimica et Cosmochimica Acta 54 (7): 2003-2013

Binh CT, Phillips MJ, Demaine H. 1997. Integrated shrimp mangrove farming systems in the Mekong delta of Vietnam. Aquacult Res 28 (8): 599-610.

Boonruang P. 1984. The rate of degradation of mangrove leaves, Rhizophora apiculata BL and Avicennia marina (Forsk.) Vierh. at Phuket Island, western Peninsula of Thailand. Proceedings of Asian Symposium on Mangrove Environmental Research and Management. UNESCO (pp. 200-208). 
Boyd CE. 1989. Water quality management and aeration in shrimp farming. Alabama Agricultural Experiment Station (AAES) Reports, Auburn University.

Busacker GP, Adelman TR, Goolish EM. 1990. Methods for Fish Biology. American Fisheries Society, Bethesda, Md., USA. 363-387.

Camilleri J. 1989. Leaf choice by crustaceans in a mangrove forest in Queensland. Mar Biol 102 (4): 453-459.

Chin TS, Chen JC. 1987. Acute toxicity of ammonia to larvae of the tiger prawn, Penaeus monodon. Aquaculture 66 (3): 247-253.

Chyau CC, Ko PT, Mau JL. 2006. Antioxidant properties of aqueous extracts from Terminalia catappa leaves. LWT-Food Sci Technol 39 (10): 1099-1108

Clough B, Johnston D, Xuan TT, Phillips MJ, Pednekar SS, Thien NH, Thong PL. 2002. Silvofishery farming systems in Ca Mau province, Vietnam. The World Bank, NACA, WWF and FAO Consortium Program on Shrimp Farming and the Environment. Work in Progress for Public Discussion, Published by the Consortium.

Davis SE, Corronado-Molina C, Childers DL, Day JW. 2003. Temporally dependent $\mathrm{C}, \mathrm{N}$, and $\mathrm{P}$ dynamics associated with the decay of Rhizophora mangle L. leaf litter in oligotrophic mangrove wetlands of the Southern Everglades. Aquat Bot 75 (3): 199-215.

Dick TM, Osunkoya OO. 2000. Influence of tidal restriction floodgates on decomposition of mangrove litter. Aquat Bot 68 (3): 273-280.

Erickson AA, Bell SS, Dawes CJ. 2004. Does mangrove leaf chemistry help explain crab herbivory patterns?. Biotropica 36 (3): 333-343.

Fitzgerald WJ. 2002. Silvofisheries: Integrated mangrove forest aquaculture systems. Ecological Aquaculture: The Evolution of the Blue Revolution, pp. 161-262.

Fitzgerald WJ. 2000. Integrated mangrove forest and aquaculture systems in Indonesia. In Mangrove-Friendly Aquaculture; Proceedings of the Workshop on Mangrove-Friendly Aquaculture organized by the SEAFDEC Aquaculture Department, January 11-15, 1999, Iloilo City, Philippines (pp. 21-34). Southeast Asian Fisheries Development Center, Aquaculture Department.

Hai TN, Yakupitiyage A. 2005. The effects of the decomposition of mangrove leaf litter on water quality, growth, and survival of black tiger shrimp (Penaeus monodon Fabricius, 1798). Aquaculture 250 (3): $700-712$

Hammann S, Zimmer M. 2015. Lifestyles of Detritus-feeding Crustaceans. Lifestyles and Feeding Biology 479-501.

Harlina H, Prajitno A, Suprayitno E, Nursyam H. 2015. Potential study of kopasanda (Chromolaena odorata L.) leaves as antibacterial against vibrio harveyi, disease causative agent of tiger shrimp (Penaeus monodon Fabricius) postlarvae. J Aquacult Res Develop 2015.

Hernes PJ, Benner R, Cowie GL, Goñi MA, Bergamaschi BA, Hedges JI 2001. Tannin diagenesis in mangrove leaves from a tropical estuary: A novel molecular approach. Geochimica et Cosmochimica Acta 65: 3109-3122.

Hendrajat EA. 2007. Culture of vannamei shrimp (Litopenaeus vannamei) with traditional method improvement in Maros, South Sulawesi. Aquacult Media 2 (2).

Ikhwanuddin M, Moh JH, Hidayah M, Noor-Hidayati AB, Aina-Lyana NM, Juneta ASN. 2014. Effect of Indian almond, Terminalia catappa leaves water extract on the survival rate and growth performance of black tiger shrimp, Penaeus monodon postlarvae. AACL Bioflux 7 (2): 85-93.

Johnston D, Lourey M, Van Tien D, Luu TT, Xuan TT. 2002. Water quality and plankton densities in mixed shrimp mangrove forestry farming systems in Vietnam. Aquacult Res 33 (10): 785-798.

Johnston D, Van Trong N, Van Tien D, Xuan TT. 2000. Shrimp yields and harvest characteristics of mixed shrimp-mangrove forestry farms in southern Vietnam: factors affecting production. Aquaculture 188 (3): $263-284$
Maitra S, Ray AK. 2003. Inhibition of digestive enzymes in rohu, Labeo rohita (Hamilton), fingerlings by tannin: an in vitro study. Aquacult Res 34 (1): 93-95.

Mangampa et al. 2014. Field assessment of tiger shrimp (Penaeus monodon), milkfish (Chanos chanos), and seaweed (Gracilaria verucosa) with polyculture technology in brackishwater pond Borimasunggu village, Maros District. Ind J Fish Sci Technol 10 (1): 30-36.

Neilson MJ, Giddins RL, Richards GN. 1986. Effect of tannins on the palatability of mangrove leaves to the tropical sesarminid crab Neosarmatium smithi. Mar Ecol Prog Ser 34 (1-2): 185-186.

Nga BT, Roijackers R, Nghia TT, Ut VN, Scheffer M. 2006. Effects of decomposing Rhizophora apiculata leaves on larvae of the shrimp Penaeus monodon. Aquacult Int 14 (5): 467-477.

Nugroho RA, Manurung H, Saraswati D, Ladyescha D, Nur FM. 2016. The effects of Terminalia catappa L. leaves extract on the water quality properties, survival and blood profile of ornamental fish (Betta sp.) cultured. Biosaintifika: J Biol Biol Educ 8 (2): 241-248.

Primavera JH. 1997. Socio economic impacts of shrimp culture. Aquacult Res 2 (10): 815-827.

Primavera JH. 2000. Integrated mangrove-aquaculture systems in Asia. Integrated Coast Zone Manag 2000, 121-128.

Primavera JH, Lavilla-Pitogo CR, Ladja JM, Pena MD. 1993. A survey of chemical and biological products used in intensive prawn farms in the Philippines. Mar Pollut Bull 26 (1): 35-40.

Rajendran N, Kathiresan K. 2000. Biochemical changes in decomposing leaves of mangroves. Chem Ecol 17 (2): 91-102.

Rajendran N, Kathiresan K. 2007. Microbial flora associated with submerged mangrove leaf litter in India. Rev Biol Trop 55 (2): 393400.

Ray WM, Chien YH. 1992. Effects of stocking density and aged sediment on tiger prawn, Penaeus monodon, nursery system. Aquaculture 104 (3-4): 231-248.

Rice EW, Baird RB, Eaton AD, Clesceri LS. 2012. Standard methods for the examination of water and wastewater. American Public Health Association, American Water Works Association, Water Environment Federation, Washington, DC.

Rivera-Ferre MG. 2009. Can export-oriented aquaculture in developing countries be sustainable and promote sustainable development? The shrimp case. J Agricult Environ Ethics 22 (4): 301-321.

Robertson AI. 1988. Decomposition of mangrove leaf litter in tropical Australia. J Exp Mar Biol Ecol 16 (3): 235-247.

Rönnbäck P. 2002. Environmentally sustainable shrimp aquaculture. Unpublished manuscript. Department of Systems Ecology, Stockholm University, Sweden.

Steinke TD, Barnabas AD, Somaru R. 1990. Structural changes and associated microbial activity accompanying decomposition of mangrove leaves in Mgeni Estuary. S Afr J Bot 56 (1): 39-48.

Tam NF, Vrijmoed LLP, Wong YS. 1990. Nutrient dynamics associated with leaf decomposition in a small subtropical mangrove community in Hong Kong. Bull Mar Sci 47 (1): 68-78.

Tonneijck FH, Winterwerp H, van Weesenbeeck B, Bosma RH, Debrot AO, Noor YR, Wilms T. 2015. Building with Nature Indonesia: securing eroding delta coastlines. Ecoshape.

Tremblay L, Benner R. 2006. Microbial contributions to Nimmobilization and organic matter preservation in decaying plant detritus. Geochimica et Cosmochimica Acta 70 (1): 133-146.

Wafar S, Untawale AG, Wafar M. 1997. Litterfall and energy flux in a mangrove ecosystem. Estuar Coast Shelf Sci 44 (1): 111-124

Wickins JF. 1976. The tolerance of warm-water prawns to recirculated water. Aquaculture 9: 19-37. 